\title{
UPAYA KEPALA SEKOLAH TERHADAP KINERJA GURU STUDI KASUS DI SMP N 4 KETAPANG
}

\author{
Sukarmin \\ Kepala SMP Negeri 4 Ketapang \\ Email: sukarminn4@gmail.com
}

\begin{abstract}
Abstrak
Penelitian ini difokuskan: 1. Strategi apa saja yang dilakukan oleh kepala sekolah dalam meningkatkan profesionalisme guru di SMPN 4 Ketapang. 2. Faktor apa saja yang menjadi kendala dan pendukung dalam peningkatan profesionalisme guru di SMPN4 Ketapang. 3. Upaya yang dilakukan kepala sekolah dalam menangani faktor kendala peningkatan profesionalisme guru di SMPN 4 Ketapang Kabupaten Ketapang. Metode penelitian yang dipakai dalam penelitian ini adalah rancangan kualitatif dengan metode pengambilan data melalui wawancara, observasi dan dokumentasi. Berdasarkan hasil penelitian maka peneliti memberikan saran-saran kepada Kepala sekolah agar tetap berpegang teguh dalam melaksanakan peran kepemimpinannya sebagaimana yang telah dikembangkannya sekarang ini, peningkatan kinerja tenaga pendidik secara terus menerus diupayakan dengan semangat kekeluargaan, kebersamaan, dan keteladanan karena tercapainya tujuan pendidikan yang baik sangat tergantung dari hasil kerja dari para tenaga pendidik. Para tenaga pendidik agar senantiasa meningkatkan disiplin dan menunjukkan etoskerja yang maksimal agar permasalahan-permasalahan yang dihadapi tidak dijadikan alasan untuk berkinerja yang rendah. Dinas Pendidikan Kabupaten Ketapang diharapkan dalam melaksanakan rekrutmen kepala sekolah agar lebih didasarkan pada prosedur dan peraturan yang sesuai dengan peraturan perundang-undangan yakni harus memenuhi persyaratan-persyaratan administrasi seperti kepangkatan, masa kerja, berkedudukan sebagai tenaga fungsional, berlatar belakang pendidikan, berpengalaman, berkelakuan baik, dan loyal terhadap negara Indonesia.
\end{abstract}

\section{Kata Kunci: Meningkatkan, Kinerja Guru, Studi Kasus, Upaya Kepala Sekolah.}

\section{PENDAHULUAN}

Pendidikan merupakan bagian penting dari proses pembangunan nasional yang ikut menentukan pertumbuhan ekonomi suatu negara. Tekanan yang menuntut pertanggungjawaban mengenai relevansi dan mutu hasil pendidikan semakin besar. Ketidakpastian mengenai lowongan pekerjaan, kelangkaan sumber-sumber dan perlunya meneliti dengan cermat lembaga yang menerima pembiayaan juga menuntut pendidikan untuk memberikan investasi dalam pengembangan sumber daya manusia, di mana peningkatan kecakapan dan kemampuan diyakini sebagai faktor-faktor pendukung upaya manusia dalam mengarungi kehidupan yang penuh dengan ketidakpastian. Dalam kerangka inilah pendidikan diperlukan dan dipandang sebagai kebutuhan dasar bagi masyarakat yang ingin maju, demikian halnya bagi masyarakat Indonesia yang memiliki wilayah yang sangat luas.

Pendidikan memberikan kontribusi yang sangat besar terhadap kemajuan suatu bangsa dan merupakan suatu wahana dalam menterjemahkan pesan-pesan yang dituangkan dalam konstitusi serta sarana dalam membangun watak bangsa (Nation Character Building). Masyarakat yang memiliki kecerdasan akan berkontribusi pada kehidupan yang cerdas pula dan secara progresif akan terbentuk individu yang mandiri. Masyarakat suatu bangsa yang demikian inilah yang merupakan investasi besar untuk berjuang keluar dari krisis dan memiliki kesiapan dalam menghadapi tantangan dunia global.

Kondisi Negara Kesatuan Republik Indonesia yang bervariasi serta munculnya berbagai masalah mendorong pemerintah memperhatikan potensi daerah. Standardisasi bagi penyeragaman rencana 
yang terlalu terpusat menghambat pelaksanaan pembangunan karena cenderung akan berakibat pada ketidaksesuaian antara rencana pusat dan kebutuhan daerah masing-masing.

Sejalan dengan tantangan kehidupan global, peran dan tanggung jawab guru pada masa mendatang akan semakin kompleks, sehingga menuntut guru untuk senantiasa melakukan berbagai peningkatan dan penyesuaian penguasaan kompetensinya. Guru harus harus lebih dinamis dan kreatif dalam mengembangkan proses pembelajaran siswa. Guru di masa mendatang tidak lagi menjadi satu-satunya orang yang paling well informed terhadap berbagai informasi dan pengetahuan yang sedang berkembang dan berinteraksi dengan manusia di jagat raya ini. Di masa depan, guru bukan satu-satunya orang yang lebih pandai di tengah-tengah siswanya. Jika guru tidak memahami mekanisme dan pola penyebaran informasi yang demikian cepat, ia akan terpuruk secara profesional. Kalau hal ini terjadi, ia akan kehilangan kepercayaan baik dari siswa, orang tua maupun masyarakat. Untuk menghadapi tantangan profesionalitas tersebut, guru perlu berfikir secara antisipatif dan proaktif. Artinya, guru harus melakukan pembaruan ilmu dan pengetahuan yang dimilikinya secara terus menerus.

Disamping itu, guru masa depan harus paham penelitian guna mendukung terhadap efektivitas pembelajaran yang dilaksanakannya, sehingga dengan dukungan hasil penelitian guru tidak terjebak pada praktek pembelajaran yang menurut asumsi mereka sudah efektif, namum kenyataannya justru mematikan kreativitas para siswanya. Begitu juga, dengan dukungan hasil penelitian yang mutakhir memungkinkan guru untuk melakukan pembelajaran yang bervariasi dari tahun ke tahun, disesuaikan dengan konteks perkembangan ilmu pengetahuan dan teknologi yang sedang berlangsung. Agar proses pendidikan dapat berjalan efektif dan efisien, guru dituntut memiliki kompetensi yang memadai, baik dari segi jenis maupun isinya. Namun, jika kita selami lebih dalam lagi tentang isi yang terkandung dari setiap jenis kompetensi, -sebagaimana disampaikan oleh para ahli maupun dalam perspektif kebijakan pemerintah-, kiranya untuk menjadi guru yang kompeten bukan sesuatu yang sederhana, untuk mewujudkan dan meningkatkan kompetensi guru diperlukan upaya yang sungguh- sungguh dan komprehensif. Salah satu upaya yang dapat dilakukan adalah melalui optimalisasi peran kepala sekolah. Idochi Anwar dan Yayat Hidayat Amir (2000) mengemukakan bahwa "kepala sekolah sebagai pengelola memiliki tugas mengembangkan kinerja personel, terutama meningkatkan kompetensi profesional guru." Perlu digarisbawahi bahwa yang dimaksud dengan kompetensi profesional di sini, tidak hanya berkaitan dengan penguasaan materi semata, tetapi mencakup seluruh jenis dan isi kandungan kompetensi sebagaimana telah dipaparkan di atas.

Dalam upaya meningkatkan mutu pendidikan nasional, pemerintah khususnya melalui Depdiknas terus menerus berupaya melakukan berbagai perubahan dan pembaharuan sistem pendidikan kita. Salah satu upaya yang sudah dan sedang dilakukan, yaitu berkaitan dengan faktor guru. Lahirnya Undang-Undang No. 14 tahun 2005 tentang Guru dan Dosen dan Peraturan Pemerintah No. 19 Tahun 2005 tentang Standar Nasional Pendidikan, pada dasarnya merupakan kebijakan pemerintah yang didalamnya memuat usaha pemerintah untuk menata dan memperbaiki mutu guru di Indonesia. Michael G. Fullan yang dikutip oleh Suyanto dan Djihad Hisyam (2000) mengemukakan bahwa "educational change depends on what teachers do and think...". Pendapat tersebut mengisyaratkan bahwa perubahan dan pembaharuan sistem pendidikan sangat bergantung pada "what teachers do and think ". Atau dengan kata lain bergantung pada penguasaan kompetensi guru. Jika kita amati lebih jauh tentang realita kompetensi guru saat ini agaknya masih beragam. Sudarwan Danim (2002) mengungkapkan bahwa salah satu ciri krisis pendidikan di Indonesia adalah guru belum mampu menunjukkan kinerja (work performance) yang memadai. Hal ini menunjukkan bahwa kinerja guru belum sepenuhnya ditopang oleh derajat penguasaan kompetensi yang memadai, oleh karena itu perlu adanya upaya yang komprehensif guna meningkatkan kompetensi guru.Tulisan ini akan memaparkan tentang apa itu kompetensi guru dan bagaimana upaya-upaya untuk meningkatkan kompetensi guru dilihat dari peran kepala sekolah. Dengan harapan kiranya tulisan ini dapat dijadikan sebagai bahan refleksi bagi para guru maupun pihak-pihak lain yang berkepentingan dengan pendidikan. 
Untuk meningkatkan kualitas dan efektivitas mengajar guru, banyak faktor yang mempengaruhinya, di antaranya adalah kepemimpinan kepala sekolah, sebab kepala sekolah merupakan orang yang berperan penting dalam mengatur aktivitas proses belajar mengajar. Di samping itu kepala sekolah juga bertanggung jawab langsung terhadap pelaksanaan segala jenis dan bentuk peraturan atau tata tertib yang harus dilaksanakan baik oleh guru maupun oleh siswa.

Kepala sekolah juga memegang peranan penting dan strategis dalam menjalankan roda pendidikan. Untuk itu kepemimpinan kepala sekolah turut mempengaruhi keteladanan guru dan siswa dalam proses belajar mengajar. Baik buruknya proses pendidikan disuatu sekolah banyak ditentukan oleh kepemimpinan kepala sekolah, sebab kepala sekolahlah orang yang paling bertanggung jawab atas segala sesuatunya yang sudah, sedang dan yang akan terjadi di sekolah tersebut. Untuk itu bagaimana pola dan cara serta metode yang diterapkan kepala sekolah melalui kepemimpinannya akan mempengaruhi para guru dalam mengajar dan murid untuk belajar. Efektivitas mengajar guru akan optimal, jika kepala sekolah dapat mengatur dan membimbing guru-guru secara baik sehingga para guru dapat melaksanakan tugas-tugasnya dengan penuh tanggung jawab, memperhatikan kepentingan dan kesejahteraan bawahannya sehingga tidak ada keluhan dalam menjalankan tugas dan kewajiban sehari-hari, harus menunjukkan kewibawaannya sehari-hari, sehingga dapat diteladani dan dipatuhi oleh para guru maupun siswa. Menetapkan dan sekaligus melaksanakan peraturan-peraturan yang logis dan sistematis, dan dapat diterima oleh semua pihak yang terkait dalam peningkatan efektivitas mengajar guru. Menurut Direktorat Pendidikan Menengah Umum, Dirjen Pendidikan Dasar dan Menengah Depdiknas 1988/1999, ada beberapa komponen yang terdapat dalam diri kepala sekolah di antaranya adalah kepala sekolah sebagai pendidik, kepala sekolah sebagai manager, kepala sekolah sebagai pemimpin.

Aspek-aspek di atas haruslah dimiliki oleh seorang kepala sekolah, kepala sekolah jangan hanya memimpin sebuah lembaga tanpa memperhatikan aspek-aspek tersebut yang harus dimilikinya. Seorang pemimpin jangan hanya bisanya mengkritik orang lain/bawahan, sementara kepala sekolah sendiripun tidak memiliki kepribadian yang baik. Jadi kepala sekolah itu harus benar-benar memiliki sesuatu yang unggul dari bawahannya, karena kita tahu bahwa pemimpin itu merupakan contoh teladan dan panutan bagi bawahannya. Di samping itu, sudah seharusnya kepala sekolah melakukan upayaupaya memberi rewards (penghargaan) dan incentives (kepedulian) bagi guru/staf atas kontribusinya terhadap pengembangan sekolah, dan bemberikan punishments (hukuman) bagi anak buah yang meremehkan kualitas, pretasi, standar, dan nilai-nilai yang telah menjadi acuan secara nasional, kepala sekolah juga berkewajiban memastikan bahwa anak buahnya memahami, menyetujui,dan mendapatkan rewards melalui kegiatan-kegiatan yang dilakukannya dalam meningkatkan efektivitas mengajar guru.

Berdasarkan uraian di atas, maka penulis merasa tertarik untuk meneliti tentang bagaimana sebenarnya kepemimpinan kepala sekolah sehingga dapat meningkatkan efektivitas mengajar guru di salah satu lembaga pendidikan formal ddengan judul "Upaya Kepala Sekolah Dalam Meningkatkan Kinerja Guru, Studi Kasus di SMP N 4 Ketapang Kabupaten Ketapang”.

\section{METODE PENELITIAN}

Rancangan penelitian yang akan digunakan dalam penelitian ini adalah studi kasus. Design ini digunakan untuk mengkaji strategi kepala sekolah dalam meningkatkan daya saing lembaga di SMP N 4 Ketapang Kabupaten dan Interaksi para warga sekolah akan dikaji dan diinterpretasikan oleh peneliti.

Sesuai dengan pendekatan kualitatif maka kehadiran peneliti di lapangan adalah sangat penting dan menentukan serta diperlukan secara optimal. Peneliti adalah instrument kunci, yang langsung bertatap muka dengan orang-orang yang terlibat dalam kajian. Data yang akan terkumpulkan dalam penelitian ini adalah perilaku yang nyata berupa penglihatan, pendengaran, pengajuan pertanyaan, dan pengumpulan bendabenda. Untuk itu, peneliti menggunakan penglihatannya, pendengarannya, (alat inderanya) (Preissle-Goetz dan LeCompte, 1981 dalam Mantja 2005). Lokasi penelitian yang dipilih oleh peneliti adalah SMP N 4 Ketapang Kabupaten 
Ketapang Dengan pertimbangan bahwa SMP N 4 Ketapang Kabupaten Ketapang.

Sumber data penelitian, menurut Suyitno (2006) dapat diklasifikasikan menjadi tiga yakni person, place dan paper. Sehingga sumber data dalam penelitian ini diklasifikasikan menjadi tiga bagian, yaitu sumber data berupa; 1) orang (person) terdiri dari : kepala sekolah, guru, siswa, orangtua murid, petugas sekolah. 2) place meliputi; lingkungan sekolah dan sarana prasarana sekolah. 3) dokumen tertulis dan tidak tertulis berupa; paper sekolah, peraturan-peraturan sekolah, pengumuman-pengumuman, hasil karya siswaa maupun guru, simbol-simbol.

Teknik pengumpulan data yaitu wawancara mendalam, observasi partisipan, observasi nonpartisipan, dan dokumentasi. Data yang telah diperoleh, dianalisis dengan menggunakan model analisis interaktif (analisis interactive model) yang dikemukan oleh Miles dan Huberman dalam Suyitno (2006). Kriteria yang digunakan dalam pengecekan keabsahan data atau pemeriksaan keabsahan data dalam penelitian ini meliputi empat hal yaitu: kredibilitas, dipendabilitas, konfirmabilitas dan transferabilitas (Suyitno, 2006). Kreadibilitas adalah suatu criteria untuk memenuhi bahwa data dan informasi yang dikumpulkan harus mengandung nilai kebenaran, yang berarti bahwa hasil penelitian kualitatif harus dapat dipercaya oleh pembaca yang kritis dan dapat diterima oleh orang-orang (responden) yang memberikan informasi yang dikumpulkan selama penelitian berlangsung.

Agar penelitian memperoleh kredibilitas yang tinggi maka Lincoln dan Guba merekomendasikan tujuh teknik yang perlu dilakukan oleh para peneliti, yaitu melakukan: prolonged engagement, persistent observation, triangulation, pear debriefing, negative case analyst, referencyal adequment, checks dan member checking.

Agar temuan penelitian ini dapat dipertahankan dan dapat dipertanggung-jawabkan secara ilmiah melalui uji keakuratan perolehan penelitian, maka peneliti melibatkan beberapa pihak ke dalam proses penelitian. Audittrail dilakukan oleh pembimbing berdasarkan dari bahan-bahan yang telah disiapkan peneliti melalui catatan lapangan waktu sewaktu wawancara, observasi, analisis data dan tafsiran atau simpulan. Cara ini dilakukan agar kekeriuan atau kesalahan di dalam mengkonseptualisasikan rencana penelitian, pengumpulan dan analisis data serta menginterpreta-sikanya dapat ditanggulangi.

Konfirmabilitas yaitu kriteria untuk menilai apakah hasil penelitian bermutu atau tidak. Jika dependability audit digunakan untuk menilai kualitas dari proses yang ditempuh oleh peneliti sampai dapat membuahkan hasil penelitian, maka Confirmability audit digunakan untuk menilai kualitas hasil penelitian itu sendiri. Nilai transformasi atau keteralihan berkenaan dengan pertanyaan, sampai dimana hasil penelitian dapat diaplikasikan dalam situasi-situasi lain, (Nasution, 1988). Pada dasarnya penerapan keteralihan merupakan suatu upaya berupa urain rinci: penggambaran konteks tempat penelitian, hasil yang ditemukan sehingga dapat dipahami oleh orang lain (pemakai). Untuk melakukan pengalihan ini, peneliti mencari dan mengumpulkan kejadian empiris tentang kesamaan konteks dalam hal ini kejadian atau peristiwa yang berhubungan dengan masalah penelitian ini.

\section{HASIL DAN PEMBAHASAN PENELITIAN}

Guru merupakan profesi, sehingga menuntut adanya profesionalisme dalam melaksanakan tugas dan kewajibannya. Profesionalisme menekankan penguasaan ilmu pengetahuan atau kemampuan manajemen beserta strategi pengembangannya. Guru memiliki tugas besar seperti diamanatkan dalam pasal 3 UU No 20 2003 tentang Sistem Pendidikan Nasional yang menyatakan bahwa " Pendidikan Nasional berfungsi mengembangkan kemampuan dan membentuk watak serta peradaban bangsa yang bermartabat dalam rangka mencerdaskan kehidupan bangsa, bertujuan untuk berkembangnya potensi peserta didik agar menjadi manusia yang beriman dan bertaqwa kepada Tuhan Yang Maha Esa, berakhlaq mulia, sehat, berilmu, cakap, kreatif, mandiri dan menjadi warga negara yang demokratis serta bertanggungjawab". Dalam rangka untuk mendukung peningkatan profesionalisme guru tersebut, pemerintah mengeluarkan kebijakankebijakan antara lain Undang-Undang Guru dan Dosen dimana pada kebijakan tersebut secara jelas menyebutkan bahwa guru dan dosen adalah pekerjaan profesi. 
Berdasarkan hasil Tahapan di kelas yang telah dilaksanakan dikelas VIII SMPN 3 Ketapang, dapat ditarik kesimpulan sebagai berikut, (1) keberhasilan dari penggunaan

Melalui hasil penelitian ini menunjukkan bahwa metode belajar aktif model pengajaran terarah memiliki dampak positif dalam meningkatkan prestasi belajar siswa. Hal ini dapat dilihat dari semakin mantapnya pemahaman siswa terhadap materi yang disampaikan guru (ketuntasan belajar meningkat dari siklus I, II, dan III) yaitu masing-masing 65,63\%, 75,00\%, dan $87,50 \%$. Pada siklus III ketuntasan belajar siswa secara klasikal telah tercapai.

Berdasarkan analisis data, diperoleh aktivitas siswa dalam proses belajar aktif dalam setiap siklus mengalami peningkatan. Hal ini berdampak positif terhadap prestasi belajar siswa yaitu dapat ditunjukkan dengan meningkatnya nilai rata-rata siswa pada setiap siklus yang terus mengalami peningkatan.

Berdasarkan analisis data, diperoleh aktivitas siswa dalam proses pembelajaran IPS pada pokok bahasan Makna peninggalan-peninggalan sejarah yang berskala nasional dan masa Hindu-Budha, dan Islam di Indonesia dengan metode belajar aktif model pengajaran terarah yang paling dominant adalah bekerja dengan menggunakan alat/media, mendengarkan/ memperhatikan penjelasan guru, dan diskusi antar siswa/antara siswa dengan guru. Jadi dapat dikatakan bahwa aktivitas isiwa dapat dikategorikan aktif.

Sedangkan untuk aktivitas guru selama pembelajaran telah melaksanakan langkah-langkah belajar aktif dengan baik. Hal ini terlihat dari aktivitas guru yang muncul di antaranya aktivitas membimbing dan mengamati siswa dalam mengerjakan kegiatan LKS/menemukan konsep, menjelaskan materi yang tidak dimengerti, memberi umpan balik/evaluasi/tanya jawab dimana prosentase untuk aktivitas di atas cukup besar.

Profesi merupakan pekerjaan yang memerlukan pendidikan lanjut di dalam science dan tekhnologi. Perangkat ini digunakan sebagai perangkat dasar untuk mengimplementasikan dalam berbagai kegiatan yang bermanfaat. Ada sepuluh criteria suatu jabatan dikatakan sebagai profesi, antara lain: 1) memiliki fungsi dan signifikansi social, 2) memiliki keahlian dan ketrampilan tertentu, 3) keahlian diperoleh dengan teori dan metode ilmiah, 4) berdasarkan disiplin ilmu yang jelas, 5) Aplikasi dan sosialisasi nilainilai profesional, 6) memiliki kode etik, 7) diperoleh melalui pendidikan tertentu, 8) kebebasan memberi judgment memecahkan masalah dalam bekerja, 9) memiliki tanggung jawab professional dan otonom, 10) Ada pengakuan dari masyarakat dan imbalan atas layanan profesi.

Supervisi adalah aktivitas menentukan kondisi/ syarat yang essensial yang akan menjamin tercapainya tujuan pendidikan. Tugas Kepala Sekolah sebagai supervisor berarti bahwa ia harus meneliti, mencari,dan menentukan syaratsyarat mana saja yang diperlukan bagi kemajuan sekolahnya. Kepala sekolahharus dapat ,meneliti syarat-syarat mana saja yang telah ada dan tercukupi, dan mana yang kurang maksimal. (Daryanto 2005: 84) Supervisi pada dasarnya pelayanan yang disediakan oleh Kepala Sekolah untuk membantu pra guru agar menjadi semakin cakap atau terampil dalam melaksanakan tugasnnya sesuai dengan tuntutan perkembangan jaman. (Nawawi, H. Hadari 1995: 196).

Supervisi adalah usaha yang dilakukan Kepala Sekolah dalam membantu guru-guru agar semakin mampu mewujudkan proses belajar mengajar. Supervisi Kepala Sekolah adalah menilai kemampuan setiap personil sekolah dalam melaksanakan tugas-tugasnya, guna membantu yang bersangkutan melakukan perbaikanperbaikan bilamana diperlukan, dengan menunjukkan kekurangan-kekurangan atau kelemahan masing-masing dalam bekerja agar diatasi dengan usaha sendiri. Dengan kata lain, tujuan supervisi kepala sekolah adalah menumbuhkan kesadaran guru untuk berusaha dengan kemampuan sendiri memperbaiki kekurangan atu kelemahannya dalam melaksanakan tugas, berdasarkan hasil penilaian yang dilakukan Kepala Sekolah. (Nawawi, H. Hadari 1995: 198) Tugas Kepala Sekolah sebagai supervisor, maka ia melakukan pengawasan dan pewngendalian terhadap tenaga kependidikan khususnya guru, yang bertujuan untuk meningkatkan kemampuan provesional guru dan meningkatkan kualitas pembelajaran melalui pembelajaran yang efektif. Dalam pelaksanaannya, Kepala sekolah sebagai 
supervisor harus memperhatikan prinsip-prinsip: (1) Hubungan konsultatif, kolegial, dan bukan hirarkis, (2) Dilaksanakan secara demokratis, (3) Berpusat pada tenaga kependidikan atau Guru, (4) Dilakukan berdasarkan kebutuhan tenaga kependidikan atau Guru, (5) Merupakan bantuan profesional. (E. Mulyasa 2004: 113). Manusia merupakan intangible resources yang diyakini mampu mengembangkan pengetahuan atau knowledge, artinya semakin baik knowledge atau pengetahuan yang diterima manusia maka pengetahuan itu akan dapat menciptakan pengetahuan baru yang lebih baik lagi.

Menjadi guru bukan sebuah proses yang hanya dapat dilalui, diselesaikan, dan ditentukan melalui uji kompetensi dan sertifikasi. Karena menjadi guru menyangkut perkara hati, mengajar adalah profesi hati. Hati harus banyak berperan atau lebih daripada budi. Oleh karena itu, pengolahan hati harus mendapatkan perhatian yang cukup, yaitu pemurnian hati atau motivasi untuk menjadi guru. Salah satu indikator untuk menentukan kualitas sumber daya manusia adalah tingkat pengetahuan yang dimiliki, karena pengetahuan menjadi sumber daya utama untuk pembangunan sosial, ekonomi dan politik. Untuk itu, pendidikan ditempatkan pada posisi yang menentukan, karena manusia yang berpengetahuan adalah keluaran dari suatu pendidikan baik formal, nonformal, maupun informal.

La Ode Turin (2005:2) mengungkapkan bahwa dalam meningkatkan mutu pendidikan, faktor utama yang menjamin sekolah lebih baik adalah apabila sekolah tersebut memiliki guruguru yang baik, karena itu harapan untuk memiliki sekolah yang baik dalam arti berkualitas tinggi harus didahului dengan pembinaan terhadap gurunya. Kemerosotan pendidikan kita sudah terasakan selama bertahun-tahun, untuk kesekian kalinya kurikulum dituding sebagai penyebabnya. Hal ini tercermin dengan adanya upaya mengubah kurikulum mulai kurikulum 1975 diganti dengan kurikulum 1984, kemudian diganti lagi dengan kurikulum 2006. Nasanius dalam Ani (2003:2) mengungkapkan bahwa "kemerosotan pendidikan bukan diakibatkan oleh kurikulum tetapi oleh kurangnya kemampuan profesionalisme guru dan keengganan belajar siswa". Profesionalisme sebagai penunjang kelancaran guru dalam melaksanakan tugasnya, sangat dipengaruhi oleh dua faktor besar yaitu faktor internal yang meliputi minat dan bakat dan faktor eksternal yaitu berkaitan dengan lingkungan sekitar, sarana prasarana, serta berbagai latihan yang dilakukan guru.

Sementara itu Sumargi dalam Ani (2003:2) mengungkapkan "profesionalisme guru dan tenaga kependidikan masih belum memadai utamanya dalam hal bidang keilmuannya. Untuk dapat melaksanakan tugas dan tanggung jawab diatas, seorang guru dituntut memiliki beberapa kemampuan dan ketrampilan tertentu. Kemampuan dan ketrampilan tersebut sebagai bagian dari kompetensi profesionalisme guru. Kompetensi merupakan suatu kemampuan yang mutlak dimiliki oleh guru agar Tugasnya sebagai pendidik dapat terlaksana dengan baik. Tugas guru erat kaitannya dengan peningkatan sumber daya manusia melalui sektor pendidikan, oleh karena itu perlu upaya-upaya untuk meningkatkan mutu guru untuk menjadi tenaga professional.

Untuk dapat melaksanakan tugas dan tanggung jawab diatas, seorang guru dituntut memiliki beberapa kemampuan dan ketrampilan tertentu. Kemampuan dan ketrampilan tersebut sebagai bagian dari kompetensi profesionalisme guru. Kompetensi merupakan suatu kemampuan yang mutlak dimiliki oleh guru agar Tugasnya sebagai pendidik dapat terlaksana dengan baik.

Dorongan guru melakukan kegiatan memberi jasa sangat dipengaruhi oleh motivasi yang berasal dari dalam diri guru maupun motivasi yang berasal dari luar. Setiap kali guru menyelenggarakan kegiatan pembelajaran di kelas tentu sudah terfikir mengenai sasaran yang ingin dicapainya. Berarti sebenarnya guru telah menyadari akibat yang akan terjadi pada diri siswa setelah mengikuti pembelajaran itu. Penguasaan apa saja yang kelak dapat dimiliki siswa berikut bagaimana kelak guru dapat mengukur kemampuan siswa dengan cara mengevaluasinya. Dalam kenyataannya orientasi pembelajaran di kelas akhirnya hanya menyentuh ranah kognitif saja. Untuk mengubah paradigma tujuan guru menyelenggarakan proses pembelajaran di kelas dengan adanya kurikulum baru, haruslah dipandang secara komprehensif. Tidak tertuju hanya mengubah kebiasaan guru dalam mengajar, tetapi juga sistem penyelenggaraan pembelajaran secara utuh harus juga diperhatikan. 
Seharusnya seorang guru melakukan aktivitas mengajar karena ada motivasi yang mendasarinya. Motivasi atau motivation berarti pemberian motif, penimbulan motive atau hal yang menimbulkan dorongan atau keadaan yang menimbulkan dorongan. Motivasi dapat pula diartikan faktor yang mendorong orang untuk bertindak dengan cara tertentu. Sedang motivasi mengajar adalah dorongan yang menyebabkan seseorang guru mau melakukan sesuatu kegiatan mengajar. Dorongandorongan itu bertujuan untuk menggiatkan guru agar bersemangat dalam mengajar sehingga mencapai hasil sebagaimana dikehendaki sesuai tujuan. Dengan kata lain, motivasi mengajar yang tinggi pada hakekatnya berdampak pada kinerja guru. Ilyas dan Zuhairi (2004:3) mengungkapkan, kinerja adalah penampilan hasil karya SDM dalam suatu organisasi. Kinerja adalah hasil kerja yang dapat dicapai oleh seseorang atau sekelompok orang dalam suatu organisasi sesuai dengan wewenang dan tangungjawab masing-masing, dalam rangka upaya mencapai tujuan organisasi bersangkutan secara legal, tidak melanggar hukum dan sesuai dengan moral dan etika. Kinerja guru lebih mengarah pada tingkatan prestasi sekolah. Kinerja guru merefleksikan bagaimana seorang guru memenuhi keperluan pekerjaan dengan baik. Banyak faktor yang mempengaruhi kinerja guru diantaranya adalah sikap dan motivasi mengajar guru. Kinerja guru dengan menciptakan situasi pembelajaran yang menyenangkan bersumber pada komponen-komponen sikap, pengetahuan, ketrampilan, perbuatan atau perlakuan guru terhadap siswa. Guru yang mempunyai komitmen dan totalitas pengabdian yang besar akan berupaya memberikan perhatian yang sebaik-baiknya kepada siswanya. Selain pengaruh sikap guru, penguasaan pengetahuan dan keterampilan guru yang terlihat ketika ia membelajarkan siswasiswanya melalui ceramah, demontrasi, eksperimen, atau pemecahan masalah dapat berdampak positif terhadap siswa.

Fenomena kinerja guru yang kualitasnya diketahui dan diakui para siswa, apalagi pembelajaran yang dikelolanya itu menyenangkan, bahkan mengasikkan mereka, dan pada gilirannya menumbuhkembangkan rasa ingin tahu mereka, tentu hal ini akan mendorong mereka untuk mencari sumber cerita, penjelasan guru, dan sumber engetahuan yang berkaitan dengan kegiatan percobaan atau investigasi sederhana yang mereka lakukan.

Pada dasarnya setiap guru ingin mengetahui secara tepat prestasi kerja masing-masing. Para guru dalam suatu organisasi selalu memiliki keingintahuan dan bertanya kepada diri mereka atau kepada rekan sejawat atau kepada atasan yang mereka percayai tentang hal-hal yang terkait dengan kinerja mereka. Hal ini apakah mereka telah bekerja sesuai dengan standar kerja organisasi, dan apakah telah bekerja sesuai dengan harapan atasan langsung mereka. Untuk itu diperlukan adanya penilaian kinerja. Penilaian kinerja adalah proses menilai hasil karya SDM dalam suatu organisasi melalui instrumen penilaian kinerja. Pada hakekatnya penilaian kinerja merupakan suatu evaluasi terhadap penampilan kerja. Bila pelaksanaan pekerjaan sesuai dengan atau melebihi uraian pekerjaan, hal ini berarti pekerjaan itu berhasil dikerjakan dengan baik. Bila peniaian kinerja menunjukkan hasil di bawah uraian pekerjaan, hal ini berarti pelaksanaan pekerjaan tersebut kurang baik. Dengan demikian penilaian kinerja dapat didefinisikan sebagai proses formal yang dilakukan untuk mengevaluasi tingkat pelaksanaan pekerjaan atau unjuk kerja seorang pegawai dan memberikan umpan balik untuk kesesuaian tingkat kinerja.

\section{Garis Besar Strategi yang Dilakukan Kepala Sekolah dalam Upaya Mendisiplinkan Guru SMPN 4 Ketapang}

Strategi yang dilakukan oleh kepala sekolah dalam meningkatkan kinerja guru di SMP N 4 Ketapang Kabupaten Ketapang, yaitu

(1) Melakukan restrukturisasi organisasi ke arah ramping struktur, kaya fungsi, restrukturisasi manajemen, birokrasi yang lebih fleksibel, serta pembenahan personal (menempatkan posisi yang sesuai untuk kemampuan personal yang relevan). Diperlukan fit and proper test untuk jabatan strategis dan mempunyai tanggungjawab yang besar. (2) Aspek penting dalam penguatan sistem manajemen internal adalah leadership commitment yang harus mampu mendorong kearah keterbukaan dan otonomi unit. Harus dibangun citra penyelenggaraan lembaga yang bersih dan berwibawa (good university governance). Mewujudkan terselelenggaranya tata kelola 
kelembagaan yang otonom dan memiliki akuntabilitas yang tinggi terhadap stakeholders dalam hal pengelolaan akademik, administratif, SDM, pendanaan, dan asset sekolah. (3) Penyusunan data based staff (guru dan karyawan) beserta kompetensi, dan perencanaan karier, pengkaderan yang sistematis. Pendataan kompetensi seluruh karyawan, serta perangkat administratif yang menangani kepangkatan secara terkoordinasi, yang ditangani oleh bagian human resources development (HRD) di tingkat sekolah. (4) Membangun kerjasama tim secara berkelanjutan melalui program capacity building, dengan target utama membangun kebanggaan civitas pada institusi SMP N 4 Ketapang Kabupaten Ketapang. (5) Memperkuat sinergi dan interaksi guru, karyawan dan siswa sebagai suatu potensi kekuatan institusi. Pemberdayaan (empowering) lembaga-lembaga kesiswaan, selain ditujukan untuk meningkatkan partisipasi unsur civitas juga ditujukan untuk membangun atmosfer akademik yang kondusif (6) Memberikan kebijakan kesempatan studi lanjut, mengikuti seminar, pelatihan dan lain-lain kepada guru dan karyawan dalam rangka peningkatan kapasitasnya. (7) Mengoptimalkan fungsi-fungsi kepengawasan/supervisor kepala sekolah dalam rangka mengefektifkan kegiatan belajar-mengajar.

Faktor-faktor yang menjadi kendala dalam peningkatan profesionalisme guru di SMP N 4 Ketapang Kabupaten Ketapang: (1) Sarana dan Prasarana Pendukung Pembelajaran yang Kurang Memadai. (2) Kurangnya kesadaran dari para guru dalam peningkatan mutu pendidikan. (3) Masih adanya guru SMP N 4 Ketapang Kabupaten Ketapang belum memenuhi kualifikasi pendidik sarjana (S1). (4) Kurangnya tenaga guru yang sesuai dengan bidang ajarnya.

\section{Upaya yang dilakukan kepala sekolah dalam menangani faktor kendala peningkatan profesionalisme gru di SMP N 4 Ketapang Kabupaten Ketapang}

1. Pembinaan secara terus menerus dan berkelanjutan dilakukan oleh kepala sekolah terutama kepada guru, baik secara perseorangan atau secara umum dalam forum rapat.

2. Melalui pembinaan pribadi. Dalam pembinaan pribadi ini biasanya mereka-mereka yang punya masalah, misalnya kurang disiplin dalam melaksanakan tugas dan melalui optimalisasi kegiatan Musyawarah Guru Mata Pelajaran, Pendidikan dan Pelatihan, seminar, diskusi dan sebagainya.

3. Mengambil kebijakan dengan memberi dukungan dan memotivasi kepada para guru untuk mengikuti studi lanjut.

4. Mengusulkan kepada dinas sebagai atasan dalam hal ini Dinas Pendidikan Kabupaten Ketapang agar diberikan tenaga guru sesuai dengan kebutuhan dan kebijakan menawarkan kepada guru-guru yang ada untuk ikut mengajar rangkap.

\section{SIMPULAN DAN SARAN \\ Simpulan}

Dari paparan pada hasil dan pembahasan, maka dapat disimpulkan sebagai berikut: (1) Pembinaan secara terus menerus dan berkelanjutan dilakukan oleh kepala sekolah terutama kepada guru; (2) Kebijakan dengan memberi dukungan dan memotivasi kepada para guru untuk mengikuti studi lanjut; (3) Mengusulkan kepada dinas sebagai atasan dalam hal ini Dinas Pendidikan Kabupaten Ketapang agar diberikan tenaga guru sesuai dengan kebutuhan.

\section{Saran}

Berdasarkan hasil penelitian maka peneliti memberikan saran-saran sebagai berikut: (1) Peningkatan kinerja tenaga pendidik secara terus menerus diupayakan dengan semangat kekeluargaan, kebersamaan, dan keteladanan karena tercapainya tujuan pendidikan yang baik sangat tergantung dari hasil kerja dari para tenaga pendidik; (2) Kepada para guru para tenaga pendidik agar senantiasa meningkatkan disiplin dan menunjukkan etoskerja yang maksimal agar permasalahan-permasalahan yang dihadapi tidak dijadikan alasan untuk berkinerja yang rendah; dan (3) Bagi Dinas Pendidikan Kabupaten Ketapang Sebagai lembaga formal.

\section{DAFTAR PUSTAKA}

Mantja, W. 2007. Profesionalisasi Tenaga Kependidikan: Manajemen Pendidikan dan Supervisi Pengajaran. Malang: Elang Mas.

Mulyana, D. 2004. Metodologi Penelitian Kualitatif: Paradigma Baru Ilmu 
Komunikasi dan Ilmu Sosial lainnya. Suyanto. "Guru yang Profesional dan Efektif". Bandung: Remaja Rosda Karya.

Mulyasa, E. 2003. Kurikulum Berbasis Kompetensi,Konsek, Karakteristik dan Implementasi. Bandung: PT. Remaja Rosdakarya.

Harian Kompas, Jumat, 16 Februari 2001. Suyitno, Tanzeh, 2006. Dasar-dasar Penelitian, Surabaya. Elkhaf. 